\begin{tabular}{c} 
Volume and Issues Obtainable at Center for Sustainability Research and Consultancy \\
Journal of Business and Social Review in Emerging Economies \\
ISSN: 2519-089X (E): 2519-0326 \\
Volume 3: Issue 1June 2017 \\
CSRC \\
Journal homepage: www.publishing.globalcsrc.org/jbsee \\
\hline
\end{tabular}

\title{
Measuring Sustainable Service Quality of Malaysian Water and Sewerage Companies: A Pilot Study
}

\author{
${ }^{1}$ Abrari Salleh, ${ }^{2}$ Sha'riMohdYusof, ${ }^{3}$ Norazli Othman \\ ${ }^{1} \mathrm{PhD}$ Scholar, UTM Razak School of Engineering and Advanced Technology, UniversitiTeknologi Malaysia, \\ irarba69@yahoo.com \\ ${ }^{2}$ Professor, UTM Razak School of Engineering and Advanced Technology, UniversitiTeknologi Malaysia, \\ shari@utm.my \\ ${ }^{3}$ Senior Lecturer, UTM Razak School of Engineering and Advanced Technology, UniversitiTeknologi Malaysia, \\ norazli.kl@utm.my
}

\begin{tabular}{l}
\hline ARTICLEDETAILS \\
\hline History \\
Revised format: May 2017 \\
AvailableOnline: June 2017 \\
\hline Keywords \\
Sustainable Service Quality, \\
Water and Sewerage Services, \\
Pilot Study, \\
Regulatory, \\
Validity, \\
Exploratory Factor Analysis
\end{tabular}

JEL Classification:

L15, L19

\begin{abstract}
Purpose:The aim of this paper is to evaluate the reliability and validity of the sustainable service quality or SUSSERV instrument prior its implementation to measure service quality and sustainability among the water and sewerage companies.

Design/Methodology/Approach: The random survey data from thirty questionnaires were analyzed representing customers of water and sewerage service companies in Selangor, Kuala Lumpur, and Putrajaya.

Findings:The findings showed that SUSSERV model with six independent variables namely tangibles, reliability, responsiveness, assurance, empathy, and sustainability is a valid and reliable instrument. We recommend the sampling method be used during the final research is the quota sampling and will be based on geographical factors (districts) and category of services (water and sewerage).

Implications/Originality/Value: This paper is an attempt to fill the gap between service, product and process quality. The SUSSERV model has achieved the research objective where it can be used to measure service quality and sustainability among the Malaysian water service companies. SUSSERV will be suitable to overcome the lack of research in sustainability service quality.
\end{abstract}

(C) 2017 The authors, under a Creative Commons AttributionNonCommercial 4.0

Corresponding author's email address: irarba69@yahoo.com

Recommended citation:Salleh, A., Yusof, S.M. \& Othman, N., (2017). Measuring Sustainable Service Quality of Malaysian Water and Sewerage Companies: A Pilot Study.Journal of Business and Social Review in Emerging Economies, 3 (1), 11-22.DOI:https://doi.org/10.26710/jbsee.v3i1.25

\section{Introduction}

The issue on public water services is being discussed especially in developing countries in the area of water management (Mutikangaet. al., 2011) such as water delivery quality (Abubakar, 2016). This research will explore and explain the impact of Malaysian water and sewerage companies' service quality towards sustainability. Therefore, the main objectives of this pilot research are to determine the perceived service quality and sustainability of the water and sewerage companiesand to evaluate the reliability and validity of the instrument for sustainable service quality or SUSSERV to measure Malaysia's water and sewerage services quality. 


\section{Literature Review}

\subsection{Perspectives onQuality}

Services can be viewed as a process, product and services in term of customer's value creation and provider's activities (Gronroos, 2008). It is difficult to determine customers' expectation and whether they are satisfied with the company, its products, and its service. Numerous definitions of quality have been given by researchers, practitioners, and gurus from many perspectives. Product based and user-based approaches are normally viewed by marketing people. Conversely, most engineers viewed quality as manufacturing-based. With multiple perspectives in viewing quality, companies can take advantage of shifting perspectives on quality as a product move from design to market (Garvin, 1984). In other words, quality is when a product is cheap and easy to produce and market and at the same time makes the consumer trust and feel satisfied with the product or service. The "perceived service quality model" replaces the product features of a physical product in the consumption of services. The customers perceived what they received as the outcome of the process in which the resources are used, i.e. the technical or outcome quality of the process. The differentiation between technical quality and functional quality can be seen in the hospital and healthcare services (Abuosi and Atinga, 2013) and also in higher learning institution (Kong and Muthusamy, 2011). This is because their services involve high technology tools, equipment, and peripherals which are related to functional quality. For manufacturing with total quality management (TQM) practices, other than service quality, process and product quality are being considered as well as technical quality because there is a positive relationship between TQM practices and market orientation (Lam et. al., 2012). Process and product quality are interrelated in manufacturing whereby process quality has a direct relationship toward product quality performance and business performance(Agus and Hajinoor, 2012). Quality can also be seen from a different perspective: product quality (technical quality), process quality (functional quality) and service quality (perceived quality).

\subsection{Sustainability}

The Triple Bottom Line is a sustainability model developed by Elkington (1998) comprised of three important elements, environment (planet), social (people) and economy (profit). Sustainability that has been discussed by social science scholars basically consists of three components (Sloan, 2010; Fernando, 2012; Tajbakhsh, A. and Hassini, E., 2015; Afful-Dadzieet. al. 2016) namely (1) Economy, (2) Environment and (3) Society. However, Lehtinen(2012) suggested four criteria insustainability which is Environmental, Social, Economic, and Relationship (transparency, risk management, partnerships) factors. Sustainability was also viewed by the researcher from the aspect of the economy. There is an element of cost and benefit or profit and loss for the purpose of measuring sustainability such as costefficient model (Benedetti et. al., 2012). It can be concluded that sustainability has a positive relationship towards profitability, cost reduction, economic performance (growth) and competitive advantage thus will definitely impact the economy (Amranet. al., 2010). Sustainable development is a major challenge and proves to be a daunting task to understand the inter-related complex issues. To date, sustainable development is an important concern, probably the most important, for business and society, and even for those who for years argued in favor of the importance of change towards sustainable development, this issue is now perceived as being more apparent and urgent. Therefore, sustainability is a key issue for the business community in the twenty-first century. The current crisis resulting from rapid industrialization has caused significant social and environmental side effects (Amranet. al. 2010). The policymaker, especially in water and sewerage industry, will always want its industry to be sustainable and relevant to the consumers' needs. The change will definitely involve many parties and strong political will (Moe and Rheingans, 2006) and support should be present to achieve its objectives.

Companies wishing to achieve business excellence are intense marketing products and have resulted in shorter life cycles of new products. Business excellence will be achieved by companies which can react quickly to new market conditions and customer needs. They will also constantly look for creative solutions and continuous improvements or sustainability in products and processes. Gaining product 
sustainability is important but a difficult practice in business organizations (Ali et. al., 2013). Therefore, meeting functional requirements and sustainability is critical for product success in the current market. Products compete on the basis of not only price, functions and diversity, but also sustainability. Sustainable product or system is its ability to work continuously during its life cycle with less impact on the environment (Hosseinpouret. al., 2015). Sustainability does have an impact on the implementation of services and indirectly attributes to the quality of services. Social and economic factors are among the many attributes that are correlated with service quality.

\subsection{Modified Service Quality}

From Service Quality Model (Gronroos, 1984), then a SERVQUAL model (Parasuramanet. al., 1988) with five dimensions factors has been developed. This model employs a survey in the form of a questionnaire that can be used to measure customers' expectations of service quality in terms of these five dimensions and their perceptions of the service they received. Although SERVQUAL model is proven to be a reliable and valid tool to measure service quality, it has not stopped the researchers from enhancing or extending its capability through some modifications to suit their objectives. Some modified SERVQUAL models that have been developed include SERVPERF (Cronin and Taylor, 1992), BSQ Index (Abdullah et. al., 2011) and SSQ (Voonet. al., 2014). Other researchers used the modified SERVQUAL model to suit their research in the areas of study such as hospital and healthcare (Abuosi and Atinga, 2013); banking (Amin and Isa, 2008; AmatTaapet. al., 2011); manufacturing with TQM practices (Lam et.al. 2012). Researchers in previous studies have modified the original SERVQUAL model in order to accommodate their areas of research while this research emphasized on another area that has a major impact on service quality, sustainability factors (Economy, Environment, and Society).

\section{Methodology}

The research process on SUSSERV is sequentially carried out begins with discovering issues, research proposal, research design and strategy, pilot testing, data collection, data analysis and finally, thesis reporting as simplified in Figure 1. Pilot testing will allow improvement of the instrument that needs to be made prior to the actual data collection.

\subsection{Instrument, Data Collection, and Sample}

For the purpose of this research, the authors have developed a SUSSERV model with thirty-one attributes comprises twenty-two attributes from the original SERVQUAL model (Parasuramanet. al., 1988 and Zeithamlet. al., 1990). In addition, three attributes each from the sustainability dimension namely economy, environment and society were referred to the latest scholars are presented in Table 1 to assess the instrument's validity and reliability. Data acquired for this research is from primary data using a questionnaire that consists of three sections: Section A - General Information; Section B - Expectation (E) and Perception (P) of service quality; Section C - The important features of service quality. All the questions came in the formats of Multiple Choice, Likert Scale and Fixed Sum Scale using rating scales or response strategy to generate interval and interval data (Cooper and Schindler, 2001) that are easy to compare, tabulate and analyze. The consistency in the response categories allows trends to be tracked over time if the same questions are used. The questionnaire used 7-point Likert-scale where the respondents were asked to select the most appropriate number that corresponds to the extent they agree with a statement where 1 represent "Strongly Disagree" to 7 represent "Strongly Agree". The exploratory or pilot sample size of 30 respondents were randomly selected and the answered questionnaires were collected from the sample population representing customers of water and sewerage service providers in Selangor, Wilayah Persekutuan Kuala Lumpur and Putrajaya (Billingham, et. al., 2013). 
Figure 1: The Research Process on SUSSERV

\begin{tabular}{|c|}
\hline $\begin{array}{l}\text { Discover Issues on Service Quality of Malaysian Water and Sewerage Company } \\
\text { Define Research Question (s) } \\
\text { Refine the Research Question (s) } \\
\text { Identify the Research Objective (s) } \\
\text { - To determine the perceived sustainable service quality } \\
\text { - To develop an instrument to measure sustainable service quality } \\
\text { - To determine the differences between the water and sewerage companies } \\
\end{array}$ \\
\hline $\begin{array}{c}\text { Research Design - Modified SERVQUAL } \\
\text { (5 Existing + } 1 \text { New) Dimensions } \\
\text { Design Strategy } \\
\text { (Data Collection + Sampling Method) } \\
\text { Questions and Instrument Pilot Testing } \\
\text { Research Design - Modified SERVQUAL } \\
\text { (5 Existing + } 1 \text { New) Dimensions } \\
\text { Design Strategy } \\
\text { (Data Collection + Sampling Method) } \\
\text { Questions and Instrument Pilot Testing }\end{array}$ \\
\hline $\begin{array}{c}\text { Field Data Collection } \\
\text { Data Analysis, Interpretation and Discussion }\end{array}$ \\
\hline THESIS REPORT \\
\hline
\end{tabular}

Table 1: The Additional Nine Attributes of Sustainable Service Quality Sustainable Dimension (S)

\begin{tabular}{|c|c|}
\hline Additional Attributes - Sustainable Dimension & References for the attributes \\
\hline \multicolumn{2}{|l|}{ SUSTAINABLE - ECONOMIC } \\
\hline $\begin{array}{l}\text { S1 - Providing worth value in water/sewerage } \\
\text { service price. } \\
\text { S2 - Making profit without compromising its } \\
\text { services. } \\
\text { S3 - Having a good business relationship with its } \\
\text { suppliers. }\end{array}$ & $\begin{array}{l}\text { (Aksorn and Charoenngam, 2015); (Tajbakhsh and Hassini, } \\
\text { 2015); (Simonis, 1990) }\end{array}$ \\
\hline \multicolumn{2}{|l|}{ SUSTAINABLE - ENVIRONMENT } \\
\hline $\begin{array}{l}\text { S4 - Reducing the ecological footprint }- \text { Air } \\
\text { (pollution) }\end{array}$ & $\begin{array}{l}\text { (Aksorn and Charoenngam, 2015); (Tajbakhsh and Hassini, } \\
\text { 2015); (Simonis, 1990); (Delai and Takahashi, 2011); (Bo et. } \\
\text { al., 2007); (Frederiksen et. al., 2008) }\end{array}$ \\
\hline $\begin{array}{l}\text { S5 - Reducing the ecological footprint - Water } \\
\text { (pollution) }\end{array}$ & $\begin{array}{l}\text { (Aksorn and Charoenngam, 2015); (Tajbakhsh and Hassini, } \\
\text { 2015); (Delai and Takahashi, 2011); (Frederiksen et. al., 2008); } \\
\text { (Simonis, 1990); }\end{array}$ \\
\hline $\begin{array}{l}\text { S6 - Reducing the ecological footprint - Land } \\
\text { (destruction) }\end{array}$ & $\begin{array}{l}\text { (Aksorn and Charoenngam, 2015); (Delai and Takahashi, } \\
\text { 2011); (Frederiksenet. al., 2008); (Simonis, 1990); }\end{array}$ \\
\hline \multicolumn{2}{|l|}{ SUSTAINABLE - SOCIAL } \\
\hline S7 - Having a good working place. & $\begin{array}{l}\text { (Aksorn and Charoenngam, 2015); (Tajbakhsh and Hassini, } \\
\text { 2015); (Delai and Takahashi, 2011); (Enquistet. al., 2007); } \\
\text { (Simonis, 1990); }\end{array}$ \\
\hline S8 - Having a good community. & $\begin{array}{l}\text { (Aksorn and Charoenngam, 2015); (Tajbakhsh and Hassini, } \\
\text { 2015); (Delai and Takahashi, 2011); (Simonis, 1990); }\end{array}$ \\
\hline S9 - Having knowledge workers/ organization & $\begin{array}{l}\text { (Aksorn and Charoenngam, 2015); (Delai and Takahashi, } \\
\text { 2011); (Simonis, 1990); }\end{array}$ \\
\hline
\end{tabular}




\section{Data Analysis}

In order to fulfill the pilot's objectives, reliability, descriptive and factor analyses were performed. This is to ensure the SUSSERV instrument used can precisely measure service quality in Malaysia's water and sewerage services.

\subsection{Reliability and Validity Test}

Validity test will provide some assurance and confidence in our findings (Davis and Cosenza, 2000). There are three important characteristics used to value the measurement instrument in research namely validity, reliability and practicality (Cooper and Schindler, 2001). The reliability of data from $\mathrm{N}=30$ questionnaires was tested using SPSS version 22 to measure questionnaire consistency. The overall results of reliability test indicated that the questionnaire used in this research is reliable with a Cronbach Alpha value of $>0.60$ (Hair et. al., 2010) as shown in Table 2. The content validity was carried out by asking the feedback and opinions from the expert (researchers and government officers) due to their direct involvement with water and sewerage services and understood the meaning of the sustainable concept (Joseph, 2013) on the variables and format used in the instrument, whilst construct validity of the instrument was identified using factor analysis (Cooper and Schindler, 2001).

Table 2: The Cronbach Alpha Value for Reliability Test

\begin{tabular}{|l|c|c|c|c|}
\hline $\begin{array}{c}\text { 6 SUSSERV } \\
\text { Dimensions }\end{array}$ & $\begin{array}{c}\text { Variables } \\
\text { For Expectation }\end{array}$ & $\begin{array}{c}\text { Cronbach's Alpha } \\
\text { For Expectation }\end{array}$ & $\begin{array}{c}\text { Variables } \\
\text { For Perception }\end{array}$ & $\begin{array}{c}\text { Cronbach's Alpha } \\
\text { For Perception }\end{array}$ \\
\hline Tangibles & $E 1-E 4$ & 0.632 & $P 1-P 4$ & 0.709 \\
\hline Reliability & $E 5-E 9$ & 0.951 & $P 5-P 9$ & 0.906 \\
\hline Responsiveness & $E 10-E 13$ & 0.778 & $P 10-P 13$ & 0.915 \\
\hline Assurance & $E 14-E 17$ & 0.959 & $P 14-P 17$ & 0.878 \\
\hline Empathy & $E 18-E 22$ & 0.787 & $P 18-P 22$ & 0.808 \\
\hline Sustainability & $E 23-E 31$ & 0.951 & $P 23-P 31$ & 0.844 \\
\hline Overall & & $\mathbf{0 . 9 5 7}$ & & $\mathbf{0 . 9 6 1}$ \\
\hline
\end{tabular}

\subsection{Descriptive Analysis and Analysis of Variance (ANOVA)}

The demographic information of the respondents indicated that the sample comprised water supply services $(53 \%)$ and sewerage services $(47 \%)$. The locations or area which services were delivered to respondents represented $77 \%$ in Selangor while only 23\% in Wilayah Persekutuan Putrajaya and Kuala Lumpur areas. The type of customers' household ranges from Bungalow (7\%); Semi-Detached (10\%); Terrace (66\%); Condominium (7\%); Apartment (7\%) and Low-Medium Cost houses (3\%). The results of the descriptive statistical analysis of customers' perceptions of water and sewerage services are shown in Table 3.

The gaps between Perception and Expectation on each of the Water and Sewerage Services indicates the mean scores of customers' perceptions of water services ranged from 3.44 to 5.19 whereby the mean scores for customers' expectation on water services ranged from 4.06 to 6.38 thus the gap scores ranged from -0.62 to -2.00 . The lowest perceived quality item (water services) with highest negative gap score of -2.00 was 'give customers personal service', which indicates that the water company has less empathy or lost their personal touch on giving customers personal service. The mean scores of customers' perceptions of sewerage services ranged from 4.20 to 5.27 whereby the mean scores of customers' expectation on sewerage services ranged from 5.53 to 6.13 thus the gap scores ranged from -0.67 to -1.73 . The lowest perceived quality item (sewerage services) with highest negative gap score of -1.73 was 'provide the service at the time it promised to do so', which indicates that sewerage company needs to provide services as promised or stated in the clients' charter as perceived by their customers.

The overall mean score for service quality perception items for water and sewerage services were 4.51 
and 4.84 respectively as compared to the overall mean score for service quality expectation items for water and sewerage services which were 6.00 and 5.86 respectively. These scores indicate a customer expectation on water and sewerage companies regarding service quality because the standard of living is rising and Malaysian customers expecting more quality of services, especially in water and sewerage.

Table 3: The Gaps between Perception and Expectation on Water and Sewerage Services

\begin{tabular}{|c|c|c|c|c|c|c|c|}
\hline \multirow{2}{*}{ 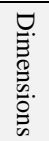 } & \multirow[b]{2}{*}{$\begin{array}{c}\text { Variable } \\
\text { No. }\end{array}$} & \multicolumn{3}{|c|}{ WATER SERVICES } & \multicolumn{3}{|c|}{ SEWERAGE SERVICES } \\
\hline & & $\begin{array}{c}\text { Mean } \\
\text { Perception }\end{array}$ & $\begin{array}{c}\text { Mean } \\
\text { Expectation }\end{array}$ & $\begin{array}{c}\text { Gap } \\
\text { Score }\end{array}$ & $\begin{array}{c}\text { Mean } \\
\text { Perception }\end{array}$ & $\begin{array}{c}\text { Mean } \\
\text { Expectation }\end{array}$ & $\begin{array}{c}\text { Gap } \\
\text { Score }\end{array}$ \\
\hline \multirow{4}{*}{ 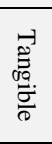 } & 1 & 4.19 & 6.13 & -1.94 & 5.00 & 5.67 & -0.67 \\
\hline & 2 & 4.38 & 5.63 & -1.25 & 4.64 & 5.67 & -1.03 \\
\hline & 3 & 4.50 & 6.00 & -1.50 & 5.14 & 5.87 & -0.73 \\
\hline & 4 & 4.44 & 5.88 & -1.44 & 5.00 & 5.87 & -0.87 \\
\hline \multirow{5}{*}{ 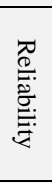 } & 5 & 4.44 & 5.94 & -1.50 & 4.60 & 5.53 & -0.93 \\
\hline & 6 & 4.63 & 5.81 & -1.18 & 4.60 & 5.60 & -1.00 \\
\hline & 7 & 4.38 & 5.88 & -1.50 & 4.33 & 5.80 & -1.47 \\
\hline & 8 & 4.44 & 6.00 & -1.56 & 4.27 & 6.00 & -1.73 \\
\hline & 9 & 4.44 & 5.75 & -1.31 & 4.53 & 5.93 & -1.40 \\
\hline \multirow{4}{*}{ 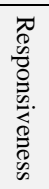 } & 10 & 4.63 & 6.25 & -1.62 & 4.80 & 5.93 & -1.13 \\
\hline & 11 & 4.56 & 6.19 & -1.63 & 4.47 & 5.93 & -1.46 \\
\hline & 12 & 4.69 & 6.38 & -1.69 & 5.07 & 6.07 & -1.00 \\
\hline & 13 & 4.13 & 5.50 & -1.37 & 4.80 & 5.53 & -0.73 \\
\hline \multirow{4}{*}{ 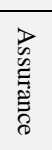 } & 14 & 4.56 & 6.25 & -1.69 & 5.20 & 6.00 & -0.80 \\
\hline & 15 & 5.00 & 6.19 & -1.19 & 5.07 & 6.00 & -0.93 \\
\hline & 16 & 4.81 & 6.19 & -1.38 & 5.27 & 6.07 & -0.80 \\
\hline & 17 & 4.75 & 6.38 & -1.63 & 5.20 & 6.13 & -0.93 \\
\hline \multirow{5}{*}{ 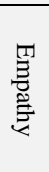 } & 18 & 4.31 & 6.31 & -2.00 & 4.93 & 6.07 & -1.14 \\
\hline & 19 & 4.81 & 6.31 & -1.50 & 4.67 & 5.73 & -1.06 \\
\hline & 20 & 3.44 & 4.06 & -0.62 & 4.20 & 5.53 & -1.33 \\
\hline & 21 & 4.06 & 5.88 & -1.82 & 4.80 & 5.73 & -0.93 \\
\hline & 22 & 4.38 & 5.94 & -1.56 & 5.00 & 6.00 & -1.00 \\
\hline \multirow{9}{*}{ 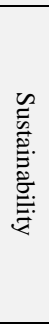 } & 23 & 4.31 & 6.19 & -1.88 & 4.67 & 5.73 & -1.06 \\
\hline & 24 & 4.19 & 5.94 & -1.75 & 5.00 & 6.07 & -1.07 \\
\hline & 25 & 4.44 & 5.69 & -1.25 & 5.00 & 5.67 & -0.67 \\
\hline & 26 & 4.63 & 6.19 & -1.56 & 4.87 & 5.93 & -1.06 \\
\hline & 27 & 4.81 & 6.25 & -1.44 & 4.87 & 5.93 & -1.06 \\
\hline & 28 & 4.56 & 6.19 & -1.63 & 5.00 & 5.80 & -0.80 \\
\hline & 29 & 4.75 & 6.06 & -1.31 & 5.00 & 6.00 & -1.00 \\
\hline & 30 & 4.94 & 6.19 & -1.25 & 5.00 & 5.87 & -0.87 \\
\hline & 31 & 5.19 & 6.31 & -1.12 & 5.13 & 6.00 & -0.87 \\
\hline \multicolumn{2}{|c|}{ Overall } & 4.51 & 6.00 & -1.49 & 4.84 & 5.86 & -1.02 \\
\hline
\end{tabular}

The Analysis of Variance (one-way ANOVA) has been performed to determine whether any of differences between means perception of the Category of Services (Water and Sewerage) and Living Status (Type of houses) are significantly different from each other. Most of the perception attributes showed no significant differences except for three of F values for Category of Services (P1, P18, P24) and one F value for Living Status (P20) were significant that measured the size of the effects or the differences between the means are shown in Table 4 . These were due to the water supply and sewerage is the same water industry and having the same perceptions. Furthermore, living status has no significant impact to differentiate for the assessment of basic needs of services especially, utility (water \& sewerage).

Table 4: Analysis of Variance of Services (Water and Sewerage) and Living Status (Type of Houses)

\begin{tabular}{|c|c|c|c|c|c|c|}
\hline \multicolumn{7}{|c|}{ One Way ANOVA (Water and Sewerage) } \\
\hline \multirow{2}{*}{ P1 } & Sum of Squares & Df & Mean Square & F & Sig. \\
\cline { 2 - 7 } & Witheen Groups & 4.929 & 1 & $\mathbf{4 . 9 2 9}$ & $\mathbf{4 . 8 5 3}$ & $\mathbf{. 0 3 6}$ \\
\cline { 2 - 7 } & Total & 28.438 & 28 & 1.016 & & \\
\hline P18 & Between Groups & 33.367 & 29 & & & \\
\hline & Within Groups & 18.36 & 28 & .656 & & \\
\hline
\end{tabular}




\begin{tabular}{|c|c|c|c|c|c|c|}
\hline & Total & 21.200 & 29 & & & \\
\hline \multirow[t]{3}{*}{ P24 } & Between Groups & 5.834 & 1 & 5.834 & 5.563 & .026 \\
\hline & Within Groups & 29.366 & 28 & 1.049 & & \\
\hline & Total & 35.200 & 29 & & & \\
\hline \multicolumn{7}{|c|}{$\begin{array}{c}\text { One Way ANOVA (Living Status - Bungalow, Semi-Detached, Terrace, Condominium, Apartment, and Low- } \\
\text { Medium Cost houses) }\end{array}$} \\
\hline & & Sum of Squares & $\mathrm{df}$ & Mean Square & $\mathrm{F}$ & Sig. \\
\hline \multirow[t]{3}{*}{ P20 } & Between Groups & 34.340 & 5 & 6.868 & 6.638 & .001 \\
\hline & Within Groups & 23.798 & 23 & 1.035 & & \\
\hline & Total & 58.138 & 28 & & & \\
\hline
\end{tabular}

\subsection{Factor Analysis}

This study uses Exploratory Factor Analysis (EFA) to uncover the underlying structure of a relatively large set of variables are shown in Table 5. Factor Analysis has been used for providing insight and information into what constitutes for each dimension especially sustainability for the purpose of data summarization and data reduction (Hair et. al., 2010). EFA was conducted using Principal Component Analysis (PCA) as the factor extraction method and used Varimax with Kaiser Normalization as the rotation method (Lai et. al., 2007). PCA required some correlations to be greater than 0.30 and all variables were correlated by more than 0.30 using Kaiser-Meyer-Olkin (KMO) Measure of Sampling Adequacy (MSA) which rotated factor value must exceed 0.50 for the overall and individual variable. Variables less than 0.50 should be removed from the factor analysis one at a time, started with the smallest ones (Hair et. al., 2010). The exploratory factor analysis extracted six factors due to a small number of cases or 30 valid cases only, which the ratio of cases to variables should be more than 5:1 (or 30 cases for 6 factors or less).

For validation, all variables have the communalities values of more than 0.50 except one variable $(\mathrm{E} 13,<$ 0.50) and all factors have been accounted for more than 60 percent of the total variance in the data based on eigenvalues greater than 1.0. Variable E13 - "never be too busy to respond to customers' requests" has been removed as the loading factor of Factor 3 due to low communalities value of only 0.254. The findings showed that almost all or $98 \%$ communalities are high therefore the sample size will not influence or have little impact on the quality of factor analysis (MacCallumet.al., 1999; Pearson and Mundfrom, 2010). The EFA results also suggested that sustainability factor has been explained by $84.6 \%$ as compared to other five existing SERVQUAL factors (Assurance, 83.1\%; Empathy, 80.4\%; Reliability, 79.5\%; Responsiveness, 77.6\%; Tangibles, 75.4\%) and the average KMO value for all factors are above 0.50 . Based on these findings, it can be concluded that all the six dimensions of SUSSERV are a valid and reliable instrument.

Table 5: Factor Analysis and Reliability Analysis on Sustainability Service Quality of Malaysian Water and Sewerage Companies

\begin{tabular}{|c|c|c|c|c|c|c|c|}
\hline & \multirow[b]{2}{*}{ Communalities } & \multicolumn{6}{|c|}{ ROTATED FACTORS } \\
\hline & & Factor 1 & Factor 2 & Factor 3 & Factor 4 & Factor 5 & Factor 6 \\
\hline Variables / Dimensions & & 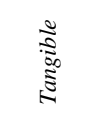 & 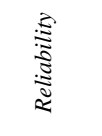 & 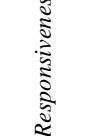 & 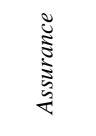 & $\begin{array}{l}\text { हे } \\
\text { है } \\
\text { है }\end{array}$ & 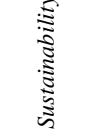 \\
\hline 1. E1 & 0.779 & 0.608 & & & & & \\
\hline 2. P1 & 0.880 & 0.929 & & & & & \\
\hline 3. E2 & 0.628 & 0.616 & & & & & \\
\hline 4. $\mathrm{P} 2$ & 0.795 & 0.726 & & & & & \\
\hline 5. E3 & 0.836 & 0.912 & & & & & \\
\hline 6. P3 & 0.704 & 0.793 & & & & & \\
\hline 7. E4 & 0.673 & 0.808 & & & & & \\
\hline 8. $\mathrm{P} 4$ & 0.736 & 0.810 & & & & & \\
\hline 9. E5 & 0.802 & & 0.823 & & & & \\
\hline 10. E5 & 0.742 & & 0.707 & & & & \\
\hline 11. E6 & 0.860 & & 0.838 & & & & \\
\hline 12. P6 & 0.688 & & 0.628 & & & & \\
\hline 13. E7 & 0.883 & & 0.822 & & & & \\
\hline 14. P7 & 0.736 & & 0.623 & & & & \\
\hline
\end{tabular}




\begin{tabular}{|c|c|c|c|c|c|c|c|}
\hline 15. E8 & 0.874 & & 0.762 & & & & \\
\hline 16. P8 & 0.902 & & 0.761 & & & & \\
\hline 17. E9 & 0.813 & & 0.743 & & & & \\
\hline 18. P9 & 0.659 & & 0.682 & & & & \\
\hline 19. E10 & 0.903 & & & 0.944 & & & \\
\hline 20. P10 & 0.779 & & & 0.880 & & & \\
\hline 21. E11 & 0.924 & & & 0.957 & & & \\
\hline 22. P11 & 0.846 & & & 0.910 & & & \\
\hline 23. E12 & 0.913 & & & 0.940 & & & \\
\hline 24. P12 & 0.829 & & & 0.904 & & & \\
\hline 25. E13 (to be removed) & $0.254(<0.50)$ & & & 0.448 & & & \\
\hline 26. P13 & 0.765 & & & 0.870 & & & \\
\hline 27. E14 & 0.919 & & & & 0.958 & & \\
\hline 28. P14 & 0.790 & & & & 0.887 & & \\
\hline 29. E15 & 0.900 & & & & 0.941 & & \\
\hline 30. P15 & 0.755 & & & & 0.867 & & \\
\hline 31. E16 & 0.897 & & & & 0.936 & & \\
\hline 32. P16 & 0.834 & & & & 0.884 & & \\
\hline 33. E17 & 0.937 & & & & 0.965 & & \\
\hline 34. P17 & 0.619 & & & & 0.781 & & \\
\hline 35. E18 & 0.839 & & & & & 0.900 & \\
\hline $36, \mathrm{P} 18$ & 0.803 & & & & & 0.864 & \\
\hline 37. E19 & 0.897 & & & & & 0.944 & \\
\hline 38. P19 & 0.921 & & & & & 0.950 & \\
\hline 39. E20 & 0.620 & & & & & 0.744 & \\
\hline 40. P20 & 0.774 & & & & & 0.818 & \\
\hline 41. E21 & 0.780 & & & & & 0.696 & \\
\hline 42. P21 & 0.808 & & & & & 0.776 & \\
\hline 43. E22 & 0.822 & & & & & 0.727 & \\
\hline 44. P22 & 0.777 & & & & & 0.663 & \\
\hline 45. E23 & 0.828 & & & & & & 0.766 \\
\hline 46. P23 & 0.719 & & & & & & 0.544 \\
\hline 47. E24 & 0.863 & & & & & & 0.791 \\
\hline 48. P24 & 0.842 & & & & & & 0.762 \\
\hline 49. E25 & 0.707 & & & & & & 0.688 \\
\hline 50. P25 & 0.759 & & & & & & 0.537 \\
\hline 51. E26 & 0.948 & & & & & & 0.957 \\
\hline 52. P26 & 0.897 & & & & & & 0.926 \\
\hline 53. E27 & 0.971 & & & & & & 0.979 \\
\hline 54. P27 & 0.741 & & & & & & 0.840 \\
\hline 55. E28 & 0.960 & & & & & & 0.974 \\
\hline 56. P28 & 0.836 & & & & & & 0.887 \\
\hline 57. E29 & 0.957 & & & & & & 0.887 \\
\hline 58. P29 & 0.766 & & & & & & 0.716 \\
\hline 59. E30 & 0.887 & & & & & & 0.935 \\
\hline 60. P30 & 0.850 & & & & & & 0.886 \\
\hline 61. E31 & 0.892 & & & & & & 0.931 \\
\hline 62. P31 & 0.804 & & & & & & 0.675 \\
\hline $\begin{array}{l}\text { Kaiser-Meyer-Olkin (KMO) } \\
\text { Measure of Sampling Adequacy (MSA) }\end{array}$ & & 0.502 & 0.523 & 0.745 & 0.756 & 0.636 & 0.725 \\
\hline Bartlett's Test of Sphericity (p-value) & & $<0.0001$ & $<0.0001$ & $<0.0001$ & $<0.0001$ & $<0.0001$ & $<0.0001$ \\
\hline $\begin{array}{l}\text { Eigenvalue/ Extraction Method: Principal } \\
\text { Component Analysis }\end{array}$ & & 6.03 & 7.96 & 6.21 & 6.65 & 8.06 & 15.29 \\
\hline $\begin{array}{l}\text { \% Cumulative Variance Explained } \\
\text { Principal Component Analysis (PCA) }\end{array}$ & & $75.4 \%$ & $79.5 \%$ & $77.6 \%$ & $83.1 \%$ & $80.41 \%$ & 84.6 \\
\hline Cronbach's Alpha (by Factor) & & 0.64 & 0.886 & 0.770 & 0.82 & 0.788 & 0.877 \\
\hline Number of items & & 8 & 10 & 8 & 8 & 10 & 18 \\
\hline
\end{tabular}

\subsection{Discussions and Recommendations}

Based on the above results and analysis indicated that all dimensions were negatively perceived meaning dissatisfaction among the respondents towards services rendered by both water and sewerage companies. The EFA results proposed that sustainability factor have been satisfactorily explained and the data for all factors (KMO) are suitable for factor analysis especially reliability and sustainability factors of the SUSSERV instrument. The overall goal of this research, therefore, will be to implement the SUSSERV model to existing Malaysian water services industry.

There is a lack of research in service quality particularly in the context of Malaysian water services industry. This paper is an attempt to fill the gap between services, product and process quality by 
including sustainability. The water and sewerage companies shouldprovide information to customersabout how it is meeting its responsibilities in relation to sustainable water usage, resources and how customersmay conserve water, more research is required to widen the applicable and perspective of sustainable development, especially on water and wastewater management. Future research can also be extended to other states by using SUSSERV especially when sustainable service quality is an imperative element.

However, this pilot study has a limitation on the small sample size and quota sampling method is suggested to be used during the final research (Voon and Murray, 2014; Amin and Isa, 2008) based on geographical factors (districts) and category of services due to the total population is too large. The quota will be based on the number and percentage of account holders or customers of each water and sewerage companies in a district as compared to the total population in Selangor, Putrajaya and Kuala Lumpur, to improve representativeness (Cooper and Schindler, 2001).

\section{References}

Abdullah, F., Suhaimi, R., Saban, G. and Hamali, J. (2011), "Bank Service Quality (BSQ) Index: An indicator of service performance", International Journal of Quality \& Reliability Management, 28(5), 542-555

Abubakar, I.R. (February 2016), "Quality dimensions of public water services in Abuja, Nigeria", Utilities Policy, 38, 43-51

Abuosi, A.A. and Atinga, R.A. (2013), "Service quality in healthcare institutions: establishing the gaps for policy action", International Journal of Health Care Quality Assurance, 26(5), 481-492

Afful-Dadzie, A., Afful-Dadzie, E.andTurkson, C. (2016), "A TOPSIS extension framework for reconceptualizing sustainability measurement”, Kybernetes. 45(1), 70-86

Agus, A. and Hajinoor, M.S. (2012), "Lean production supply chain management as driver towards enhancing products quality and business performance: case research of manufacturing companies in Malaysia", International Journal of Quality \& Reliability Management, 29(1), 92-121

Aksorn, P. and Charoenngam, C., (2015), Sustainability factors affecting local infrastructure project, Facilities, 33(1/2): 119-143

Ali, A.J., Islam, M.A., and Howe L.P. (2013), “A research of sustainability of continuous improvement in the manufacturing industries in Malaysia", Management of Environmental Quality: An International Journal, 24(3), 408-426

AmatTaap, M., Chong, S.C., Kumar, M.and Fong, T.K. (2011), "Measuring service quality of conventional and Islamic bank: A comparative analysis", International Journal of Quality and Reliability Management, 28(8), 822-840

Amin, M. and Isa, Z. (2008), "An examination of the relationship between service quality perception and customer satisfaction.A SEM approach towards Malaysian Islamic banking”, International Journal of Islamic and Middle Eastern Finance and Management, 1(3), 191-209

Amran, A., Abdul Khalid, S.N., Abdul Razak, D. and Haron, H. (2010), "Development of MBA with specialisation in sustainable development", International Journal of Sustainability in Higher Education, 11(3), 260-273

Benedetti, L., Langeveld, J., Nieuwenhuijzen, A.F.V., Jonge, J., Klein, J., Flameling, T., Nopens, I., Zanten, O., and Weijers, S. (September 2013). Cost-effective solutions for water quality improvement in the DommelRiver supported by sewer-WWTP-river integrated modelling. Water Science and Technology, IWA Publishing, 68 (5): 965-973; DOI: 10.2166/wst.2013.312

Billingham, S. A. M., Whitehead, A. L. and Julious, S.A. (2013), “An audit of sample sizes for pilot and feasibility trials being undertaken in the United Kingdom registered in the United Kingdom Clinical Research Network database", BMC Medical Research Methodology, 13(104), 1-6

Cooper, D. M.and Schindler, P.S. (2001).Business Research Methods. $7^{\text {th }}$ ed. New York: McGraw-Hill Irwin.

Cronin, J.J. and Taylor, S.A. (1992), “Measuring Service Quality: A re-examination and extension”, 
Journal of Marketing, 56, 55-68

Cronin, J. J. (2003), "Looking back to see forward in services marketing: some ideas to consider", Managing Service Quality: An International Journal, 13(5), 332-337

Davis, D. and Cosenza, R. M. (2000).Business Research for Decision Making. $5^{\text {th }}$ ed. Pacific Grove: Duxbury Press

Delai, I. and Takahashi, S. (2011). Sustainability measurement system: a reference model proposal. Social Responsibility Journal, 7(3): 438 - 471

Elkington, J. (1998). “Accounting For the Triple Bottom Line”, Measuring Business Excellence. 2(3), 1822

Enquist, B., Edvardsson, B. and Sebhatu, S.P. (2007).Value-based service quality for sustainable business.Managing Service Quality: An International Journal. 17(4): 385-403

Fernando, R. (2012), "Sustainable globalization and implications for strategic corporate and national sustainability", Corporate Governance: The international journal of business in society, 12(4), 579589

Frederiksen, P., Mäenpää, M., and Ville Hokka (2008). The Water Framework Directive: spatial and institutional integration. Management of Environmental Quality: An International Journal, 19(1): $100-117$

Garvin, D.A. (1984), “What Does "Product Quality" Really Mean?”,Sloan Management Review. pp. 2543; http://sloanreview.mit.edu/article/

Gronroos, C. (1984). “A Service Quality Model and its Marketing Implications.European Journal of Marketing”, 18(4), 36-44

Gronroos, C. (2008), "Service logic revisited: who creates value? And who co-creates?" European Business Review, 20(4), 298-314

Hair, J. F., Black, W. C., Babin, B. J., \& Anderson, R. E. (2010).Multivariate data analysis (7th ed.), Pearson Prentice-Hall, Inc.

Hosseinpour, A., Peng, Q. and Gu, P. (2015), "A benchmark-based method for sustainable product design", Benchmarking: An International Journal, 22(4), 643-664

Joseph, C. (2013), "Understanding sustainable development concept in Malaysia", Social Responsibility Journal, 9(3), 441-453

Kong, S.M. and Muthusamy, K. (2011). "Using service gaps to classify quality attributes", The TQM Journal, 23(2), 145-163

Lai, F., Hutchinson, J., Li, D. and Bai, C. (2007), "An empirical assessment and application of SERVQUAL in mainland China's mobile communications industry", International Journal of Quality \& Reliability Management, 24(3), 244 - 262

Lam, S.Y., Lee, V.H., Ooi, K.B. and Phusavat, K. (2012), “A structural equation model of TQM, market orientation and service quality: evidence from developing country”, Managing Service Quality: An International Journal, 22(3), 281-309

Lehtinen, U. (2012), "Sustainability and local food procurement: a case study of Finnish public catering", British Food Journal, 114(8), 1053-1071

Mutikanga. H. E., Sharma, S.K. and Vairavamoorthy, K. (2011), "Multi-criteria Decision Analysis: A Strategic Planning Tool for Water Loss Management", Water Resource Management, DOI 10.1007/s11269-011-9896-9, 25, 3947-3969, (published online)

Moe, C.L. and Rheingans, R.D. (2006). Global challenges in water, sanitation and health. Journal of Water and Health. 4: 41-57; IWA Publishing

Parasuraman, A., Zeithaml, V.A. and Berry, L.L. (1988), "SERVQUAL: A Multiple-Item Scale for Measuring Consumer Perceptions of Service Quality", Journal of Retailing, 64(1), 12-40

Pearson, R.H. and Mundfrom, D.J. (November 2010), "Recommended Sample Size for Conducting Explanatory Factor Analysis on Dichotomous Data", Journal of Modern Applied Statistical Method, 9(2), 359-368

Sloan, T.W. (2010), "Measuring the Sustainability of Global Supply Chains: Current Practices and Future Directions", Journal of Global Business Management: _ 
Simonis, U.E. (1990). Beyond growth: elements of sustainable development, ISBN 3-924859-56-6; http://hdl.handle.net/10419/112255

Tajbakhsh, A. and Hassini, E. (2015), "Performance measurement of sustainable supply chains: a review and research questions", International Journal of Productivity and Performance Management, 64(6), 744-783

Voon, B.H., Lee, N. and Murray, D. (2014), "Sports service quality for event venues: evidence from Malaysia", Sports, Business and Management: An International Journal, 4(2), 125-141

Zeithaml, Z.A., Parasuraman, A. Berry, L,L. (1990). Delivering Quality Service: Balancing Customer Perceptions and Expectations. Collier Macmillan Publishers, London 
